\title{
The Constitutionality of Sex Separation in School Desegregation Plans
}

In Brown v. Board of Education, ${ }^{1}$ the Supreme Court held that statesupported segregation of students in public schools solely on the basis of race deprives the children of the minority group of equal educational opportunities $^{2}$ and thereby denies them the equal protection of the laws guaranteed by the fourteenth amendment. ${ }^{3}$ During the following term, the Court, after reemphasizing "the fundamental principle that racial discrimination in public education is unconstitutional," 4 ordered admission "to public schools on a racially nondiscriminatory basis with all deliberate speed."5

Although the mandate of Brown seems clear, the attempts to desegregate public school systems through judicial intervention during the years following the second Brown decision have met with considerable delay. ${ }^{6}$ The courts have considered desegregation plans sub-

1347 U.S. 483 (1954).

2 Id. at 493.

Today, education is perhaps the most important function of state and local governments. ... [I]t is a principal instrument in awakening the child to cultural values, in preparing him for later professional training, and in helping him to adjust to his environment. In these days, it is doubtful that any child may reasonably be expected to succeed in life if he is denied the opportunity of an education. Such an opportunity, where the state has undertaken to provide it, is a right Id. which must be made available to all on equal terms.

3 Id. at 495. Racial segregation in the public schools of the District of Columbia was held to be a denial of the due process of law guaranteed by the fifth amendment. Bolling v. Sharpe, 347 U.S. 497 (1954).

The fourteenth amendment declares, in relevant part, that "[n]o State shall . . . deny to any person within its jurisdiction the equal protection of the laws." U.S. Const. amend. XIV, § 1. Soon after the ratification of the amendment, judicial pronouncement declared the prohibitions contained therein applicable to all agencies of the states as well as to all officers and agents by whom the powers of the states are exerted. Ex parte Virginia, 100 U.S. 339, 346-7 (1879).

A school board is clearly an agent of the state. Cooper v. Aaron, 358 U.S. 1, 16 (1958); cf. Ex parte Virginia 100 U.S. 339, 346-7 (1879). Throughout this comment, the actions of the school boards are presumed to be "state action" for the purpose of discussion of the fourteenth amendment.

4 Brown v. Bd. of Educ., 349 U.S. 294, 298 (1955).

5 Id. at 301 .

6 For example, the record of one case goes as follows:

Bush v. Orleans Parish, 138 F. Supp. 336 (3-judge 1956) motion for leave to file petition for mandamus denied, 351 U.S. 948 . . (1956); 138 F. Supp. 337 (1956), 
mitted by the school boards which have employed "freedom-of-choice,"7 "free transfer," closing of public schools and subsidizing private schools, ${ }^{9}$ the "brother-sister rule,"10 "grade-a-year,"11 certain forms of geographic zoning, ${ }^{12}$ and requests for delay in the desegregation timetable. ${ }^{13}$ In the cases which tested the adequacy and acceptability of each of these devices as a means of fulfilling the mandate of Brown, the plans were struck down because the school boards failed to persuade the courts that the previously existing pattern of a dual system based on race would be altered.

Recently, in at least twelve desegregation suits in the South, the plans for school desegregation submitted by the school boards and approved by the courts have, while integrating the school systems racially, separated the public school students according to sex. ${ }^{14}$ This

aff'd 242 F.2d 156 (1957), cert. denied, 354 U.S. 921 . . (1957); 252 F.2d 253, cert. denied, 356 U.S. 969 ... (1958); 163 F. Supp. 701 (1958), aff'd 268 F.2d 78 (1959); 187 F. Supp. 42 (3-judge 1960), motion to stay denied, 364 U.S. 803 . . . (1960), aff'd 365 U.S. 569 . . (1961); 188 F. Supp. 916 (3-judge 1960), motion for stay denied, 364 U.S. $500 \ldots$ (1960), aff'd 365 U.S. 569 . . (1961); 190 F. Supp. 861 (3-judge 1960), aff'd 366 U.S. 212 ... (1961); 191 F. Supp. 871 (3-judge 1961), aff'd Denny v. Bush, 367 U.S. 908 ... (1961); 194 F. Supp. 182 (3-judge 1961), aff'd Tugwell v. Bush, 367 U.S. 907 ... (1961), Gremillion v. United States, 368 U.S. 11 . . (1961); 204 F. Supp. 568 (1962), 205 F. Supp. 893 (1962), aff'd in part and rev'd in part, 308 F.2d 491 (1962); 230 F. Supp. 509 (1963).

United States v. Jefferson County, 372 F.2d 836, 860 n.51 (5th Cir. 1966), adopted en banc, 380 F.2d 385 (5th Cir.), cert. denied, 389 U.S. 840 (1967).

As the delay by the school boards and in the courts continues, the harmful effects of segregation are compounded. Green v. New Kent County, 391 U.S. 430, 438 (1968).

7 See, e.g., Raney v. Bd. of Educ., 391 U.S. 443 (1968); Green v. New Kent County, 391 U.S. 430 (1968).

8 See, e.g., Monroe v. Bd. of Comm'rs, 391 U.S. 450 (1968).

9 See, e.g., Griffin v. County School Bd., 377 U.S. 218 (1964); Hall v. St. Helena Parish, 197 F. Supp. 649 (E.D. La. 1961), aff'd, 368 U.S. 515 (1962).

10 See, e.g., Ross v. Dyer, 312 F.2d 191 (5th Cir. 1963).

11 See, e.g., Miller v. Barnes, 328 F.2d 810 (5th Cir. 1964).

12 See, e.g., Henry v. Clarksdale, 409 F.2d 682 (5th Cir. 1969).

13 See, e.g., Alexander v. Holmes County, 396 U.S. 19 (1969); Cooper v. Aaron, 358 U.S. 1 (1958). "The contrivances which some States have concocted to thwart the command of our decision in Brown $v$. Board of Education are by now legendary." Jones v. Mayer, 392 U.S. 409, 448 n.5 (1968) (Douglas, J. concurring).

14 The following are the cases in which sex separation was proposed by the school board and subsequently approved by the court, or invalidated by the court, or abandoned by the board, or is currently being litigated: Moore v. Tangipahoa Parish, 304 F. Supp. 244 (E.D. La. 1969); Charles v. Ascension Parish, Civil No. 3253 (E.D. La. 1969); Williams v. Iberville Parish, Civil No. 2921 (E.D. La. 1969); Smith v. St. Tammany Parish, 302 F. Supp. 106 (E.D. La. 1969); Banks v. St. James Parish, Civil No. 16173 (E.D. La. 1969); United States v. Carroll County, Civil No. GC 6541-K (N.D. Miss. 1969); United States v. Coffeeville Consolidated School District, Civil No. WC 6957-K (N.D. Miss. 1969); United States v. Barnwell School District (D.S.C. 1969); United States v. Catahoula Parish, Civil No. 14430 (W.D. La. 1969); United States v. Morehouse Parish, Civil No. 14429 (W.D. La. 1969); United States v. Lincoln Parish, Civil No. 12071 (W.D. La. 1969); Smith v. Concordia Parish, Civil No. 11577 (W.D. La. 1969) (A parish in Louisiana is roughly equivalent to a county); United States v. Wilkinson County, Civil No. 1160(W) (S.D. Miss. 1969); 
comment will examine the question whether a school board may, consistently with the fourteenth amendment's equal protection requirements, dismantle a dual system based on race by substituting a dual system based on sex. Specifically, the sex separation in school desegregation plans will be considered as ( 1 ) a facade for the state-supported racial discrimination in public education prohibited by Brown, (2) a form of sex discrimination which results in a denial of equal educational opportunities in violation of the fourteenth amendment, and (3) an infringement upon the fundamental freedom of association guaranteed by the first and fourteenth amendments. The comment will conclude with an evaluation of the justifications which may be offered for the use of sex separation.

It is important at the outset to take note of the manner in which courts will evaluate the sex separation schemes under consideration here. These plans will not be treated as the normal action of a school board where, absent a gross abuse of discretion, the action of the school administrators will withstand legal challenge. Rather, the sex separation is part of a school desegregation plan, and the Supreme Court has made several principles abundantly clear in the area of plan evaluation. First, Brown placed squarely on the shoulders of the school board the burden of proving the adequacy of a particular plan to bring

United States v. Amite County, Civil No. 3983(J) (S.D. Miss. 1969); United States v. School Bd. of Richmond County, Civil No. 224-69-R (E.D. Va. 1969); McFerren v. County Bd. of Educ. of Fayette County, Civil No. C-65-136 (W.D. 'Tenn. 1969) (plan invalidated by McRae, J., Jan. 1970, on the grounds, inter alia, of racial motivation for the use of the sex separation device and failure of defendant-school board to sustain the burden of proof).

The plans submitted in these cases employ sex separation to varying degrees and in different ways. For instance, in St. James approximately $70 \%$ of the students are in all-boys and all-girls schools, in Concordia nearly all of the students in the system are separated by sex; in Lincoln only 480 students are separated, in St. Tammany approximately 3300 students are separated; in Concordia all gxades are separated, in Lincoln only the seventh grade is separated; in Carroll the separation proceeds in phases-a few grades per year, in Catahoula the separation is at the option of the school board. The plans are complicated formulations the details of which need not be explored. Suffice it to say that each plan involves some separation by sex in the public school system.

The Fifth Circuit has pretermitted the question of the validity of the use of sex separation several times, see, e.g., Singleton v. Jackson Municipal Separate School District, F.2d - (5th Gir. Dec. 1, 1969); United States v. Hinds County, - F.2d - (5th Cir. Nov. 7, 1969), and, without ruling on the sex-separation issue, has given approval for the 1969-70 school year to a plan employing sex separation, see United States v. Amite County, Nos. 28030 \& 28042 (5th Cir. Dec. 11, 1969) (unreported order of 3-judge panel).

Apparently, the use of sex separation in southern schools as a reaction to desegregation is not a new idea. In 1957, Tennessee passed a law authorizing school boards to "provide separate schools for persons of the male sex and persons of the female sex." TENN. LAws 1957 , ch. 98 \& 1 . This law was enacted to "dull the edge of school desegregation." McCauley, Be It Enacted: The Legislative Record, in WITH AlL Deduberate SPEED 141 (D. Shoemaker ed. 1957). See also Moore v. Tangipahoa Parish, 304 F. Supp. 244, 249 (E.D. La. 1969). 
about equal educational opportunities, ${ }^{16}$ and subsequent decisions have demanded even more. "The burden on a school board today is to come forward with a plan that promises realistically to work, and promises to work now." 16 Second, the very fact that a board has allowed time to pass without taking steps toward compliance with the mandate of the 1955 Brown decision renders any plan submitted immediately suspicious. ${ }^{17}$ Third, in assessing the effectiveness of a school desegregation plan, a significant variable is the availability to a school board of an alternative course of action. At the very least, when potentially "more promising courses of action" exist as an alternative to the board's proposal, a heavy burden of proof is placed upon the board to justify its preference for the method it has proposed. ${ }^{18} \mathrm{Fi}$ nally, the court in Brown recognized that the "[f]ull implementation of ... [equal educational opportunity] may require solution of varied local school problems."19 Yet the Court made explicit the requirement that "a prompt and reasonable start toward full compliance" be made before any request for delay, required by these problems, would be entertained. ${ }^{20}$ The Court specifically enumerated those problems which may be taken into account when requests for delay are considered.

$[T]$ he courts may consider problems related to administration, arising from the physical condition of the school plant, the school transportation system, personnel, revision of school districts and attendance areas into compact units to achieve a system of determining admission to the public schools on a nonracial basis, and revision of local laws and regulations which may be necessary in solving the foregoing problems. ${ }^{21}$

Although this enumeration does not necessarily carry any negative implication and eliminate other possible justifications for delay in school desegregation, the Court has made its position on other justifications clear and has announced a standard by which justifications for delay must be evaluated. Those justifications for delay which were

15349 U.S. at 300 (1955).

16 Green v. New Kent County, 391 U.S. 430, 439 (1968).

17 .. [W] cannot ignore the passage of a substantial period of time since the original declaration of the manifest unconstitutionality of racial practices such as are here challenged, the repeated and numerous decisions giving notice of such illegality, and the many intervening opportunities heretofore available to attain the equality of treatment which the Fourteenth Amendment commands the States to achieve. These factors must inevitably and substantially temper the present import of such broad policy considerations as may have underlain, even in part, the form of the decree ultimately framed in the Brown case.

Watson v. Memphis, 373 U.S. 526, 529-30 (1963).

See Green v. New Kent County, 391 U.S. 430, 437-8 (1968); Calhoun v. Latimer, 377 U.S. 263, 264-5 (1964); Goss v. Bd. of Educ., 373 U.S. 683, 689 (1963).

18 Green v. New Kent County, 391 U.S. 430, 439 (1968).

19349 U.S. at 299 (1955).

$20 \mathrm{Id}$. at 300.

21 Id. at $300-1$. 
enumerated in Brown are "not to be unnecessarily expanded in application." 22

The careful specification of factors relevant to a determination whether any delay in complying fully and completely with the constitutional mandate would be warranted demonstrated a concern that delay not be conditioned upon insufficient reasons or, in any event, tolerated unless it imperatively and compellingly appeared unavoidable. ${ }^{23}$

The burden of proof is again placed on the school board, this time to prove that a start toward full compliance has been made, that delay is necessary, and that their proposed plan will meet those problems which necessitate delay. ${ }^{24}$ In short, the use of a sex separation scheme must be considered in light of the particular method of evaluation demanded by the Court in determining the validity of school desegregation plans.

\section{Sex Separation as Racial Discrimination}

Gunnar Myrdal, in his study of the race problem in America, asserts that the basic purpose behind all devices of segregation and discrimination is the desire to keep black men from white women, and, to a lesser extent, white men from black women. ${ }^{25}$ The ban on sex

22 Watson v. Memphis, 373 U.S. 526, 533 (1963).

$23 \mathrm{Id}$. at 531 (emphasis added).

24 Brown v. Bd. of Educ., 349 U.S. 294, 300-1 (1955); cf. Watson v. Memphis, 373 U.S. 526, 533 (1963). See also Green v. New Kent County, 391 U.S. 430, 439 (1968). For the Court's current position on the question of delay in school desegregation, see Alexander v. Holmes County, 396 U.S. 19 (1969).

25 This theory of color caste centering around the aversion to amalgamation determines ... the white man's rather definite rank order of the various measures of segregation and discrimination against Negroes. ... [T] he ban on intermarriage and other sex relations involving white women and colored men takes precedence before everything else.

G. Myrdal, An American Dilemma 587 (2d ed. 1962); accord, Banks, Rank Order of Sensitivity to Discrimination, 15 AM. Soc. REv. 529 (1950); Edmunds, The Myrdalian Thesis: Rank Order of Discrimination, 15 PHyLon 297 (1954).

See Lonesome v. Maxwell, 123 F. Supp. 193, 202 (D. Md. 1954), rev'd sub nom., Dawson v. Mayor, 220 F.2d 386 (4th Cir. 1955), aff'd, 350 U.S. 877 (1955); G. Allport, The NATURE of Prejudice 375-7, 467 (1954); J. Dollard, Caste and Class in a Southern Town 134-72 (3d ed. 1957); B. Doyle, The Etiquette of Race Relations in the South 63-67, 118, 152 (1937); J. GreENBERG, RACE RELATIONS AND AMERICAN LAW 343-54 (1959); M. HALSEY, Color Blind 36-37 (1946); MYRDAL, supra, at 58, 60, 586-9; G. SIMPson \& J. Yinger, RAcial AND Cultural Minorities 82-84, 261-2, 268-73 (1958). See generally City of Richmond v. Deans, 37 F.2d 712 (4th Cir.), affd, 281 U.S. 704 (1930) (housing desegregation contested because it will lead to intermarriage); L. Baughman, Southern RAPE Complex (1966); E. Cleaver, 
relations between these groups, explains Myrdal, is at the core of all such acts employed by whites, and, in fact, "[i] $t$ is the end for which the other restrictions are arranged as means." ${ }^{26}$

Whether or not Myrdal's thesis is accepted, a consideration of his assertions enables one to view the use of sex separation in a very different light. Admittedly, unlike many of the devices previously employed by southern school boards which perpetuated a dual system based on race, the sex separation scheme does integrate the races. It would, at least facially, appear to end the dual system based on race which Brown forbids. Yet, despite the apparent end to racial separation provided by a sex separation scheme, it is important to note that Brown not only called for an end to separation by race, but also declared that "racial discrimination in public education is unconstitutional." 27 Thus, while the sex separation device selectively integrates the races, it may be racially discriminatory in that (1) it perpetuates a vestige of the racial caste system-the separation of opposite-sex members of the two races-and/or (2) this separation results in harms similar to those recognized in Brown as inherent in a system of pure racial segregation.

\section{A. Racially Based Conduct and the Burden of Proof}

Courts employ various criteria in order to scrutinize conduct by a state or its agents in determining whether such conduct constitutes racial discrimination. One judicial approach in examining conduct which is challenged as racially discriminatory involves an inquiry into whether there is a racial motive or purpose underlying such conduct. ${ }^{28}$

Soul on Ice 155-210 (1968); H. Garket, Breeding Down (196?); C. Hernton, SeX and RACISM IN AMERICA (1965).

The appellants in the first brief filed before the Fifth Circuit on the issue of sex separation explain the use of the device as follows:

The superintendent's testimony makes plain what must become obvious to black parents and their children if this plan goes into effect; to the school officials of Concordia, black boys are simply not good enough to be in schools with white girls, and black girls are simply not good enough to be in schools with white boys.

Brief for Appellants at 10, Smith v. Concordia Parish, No. 28342 (5th Cir., filed October 1969). See also Moore v. Tangipahoa Parish, 304 F. Supp. 244, 249 (E.D. La. 1969).

The concern about sexual activities between the races is reflected in numerous statutes. See GRFENBERG, supra at 344-54.

28 MYXRAI, supra note 25 , at 587.

27349 U.S. at 298 (1955) (emphasis added).

28 See, e.g., Johnson v. Branch, 364 F.2d 177 (4th Cir. 1966), cert. denied, 385 U.S. 1003 (1967); Chambers v. Hendersonville Bd. of Educ., 364 F.2d 189 (4th Cir. 1966); Downs v. Bd. of Educ., 336 F.2d 988 (10th Cir. 1964), cert. denied, 380 U.S. 914 (1965); Taylor v. Bd. of Educ., 294 F.2d 36 (2d Cir.), cert. denied, 368 U.S. 940 (196I); Hobson v. Hansen, 269 F. Supp. 401, 429, $499-501$ (D.D.C. 1967), aff'd sub nom., Smuck v. Hobson, 408 F.2d 175 
If the use of sex separation by the school boards is found to be designed to perpetuate the separation of opposite-sex members of the two races, an even heavier burden of proof than is normally required in justifying a school desegregation plan may be imposed upon the school board.

If the conduct of the school board is found to be racially based, it is clear that the plans will be subjected to "the most rigid scrutiny"20 as are all classifications based on race..$^{30}$ In fact, a presumption of unconstitutionality of any measure involving racially-based classification, when employed by a state, has been repeatedly advocated. ${ }^{31}$ The rapid invalidation of racial classifications in non-education areas ${ }^{32}$-invalidation ordered without regard to the establishment of a harm-which followed the decision in the School Desegregation Cases might be cited

(D.C. Cir. 1969); cf. Swain v. Alabama, 380 U.S. 202, 203-5 (1965); Hall v. St. Felena Parish, 197 F. Supp. 649, 652 (E.D. La. 1961), aff'd, 368 U.S. 515 (1965).

In order to avoid becoming embroiled in the problem of whether the desire of school boards to separate opposite-sex members of the two races is their "motive," or "purpose," this comment will use "motive," "purpose," "desire," and "basis" to indicate the forces and goals motivating the school boards which are not beyond the scope of judicial inquiry.

Apparently the Fifth Circuit regards an inquiry into the motivation of the school boards as a proper method of challenging the plans.

The difficult question presented on a motion to approve a plan for the assignment of students by sex, once the school district has been ordered to convert to a unitary system, comes in determining whether the plan stems from educational purposes as distinguished from racially discriminatory purposes. Stated differently, is racial discrimination the motivation for the plan or does it have its basis in educational purposes?

United States v. Amite County, Nos. 28030 \& 28042 (5th Cir. Dec. 11, 1969) (unreported order of 3-judge panel).

29 Korematsu v. United States, 323 U.S. 214, 216 (1944).

30 The so-called "suspect classifications" include race, see, e.g., McLaughlin v. Florida, 379 U.S. 184 (1964); national ancestry, see, e.g., Korematsu v. United States, 323 U.S. 214 (1944); alienage, see, e.g., Sei Fujii v. State, 38 Cal. 2d 718, 242 P.2d 617 (1952); and, possibly, wealth, see, e.g., Griffin v. Mllinois, 351 U.S. 12 (1956), and religion, see, e.g., Braunfield v. Brown, 366 U.S. 599 (1961).

31 See, e.g., McLaughlin v. Florida, 379 U.S. 184, 198 (1964) (Stewart, J. and Douglas, J. concurring); Kaplan, Segregation Litigation and the Schools-Part II: The General Northern Problem, 58 Nw. U.L. REv. 157, 171-4, 179 (1963); cf. Wechsler, Toward Neutral Principles of Constitutional Law, 73 HARv. L. REv. 1, 32 (1959). See also Pollack, Racial Discrimination and Judicial Integrity: A Reply to Professor Wechsler, 108 U. PA. L. REv. I (1959).

32 See, e.g., Schiro v. Bynum, 375 U.S. 395 (1964) (municipal auditoriums); Johnson v. State of Virginia, 373 U.S. 61 (1963) (courtrooms); State Athletic Comm'n v. Dorsey, 359 U.S. 533 (1959) (athletic contests); New Orleans City Park Improvement Ass'n v. Detiege, 358 U.S. 54 (1958) (public parks and golf courses); Gayle v. Browder, 352 U.S. 903 (1956) (intrastate buses); Holmes v. Atlanta, 350 U.S. 879 (1955) (municipal golf courses); Mayor of Baltimore v. Dawson, 350 U.S. 877 (1955) (public beaches and bathhouses); Muir v. Louisville Park Theatrical Ass'n, 347 U.S. 971 (1954) (municipal amphitheater). For lower court decisions to the same effect, see cases collected in T. EMERSON, D. HABER \& N. DorSEN, POLItical and GiviL Rights in the UNITEd States 1678 (3d ed. 1967). 
for the proposition that such a presumption is, in fact, operative.33 However, recent cases before the Supreme Court which have involved racially-based classifications have not been summarily dealt with through the use of any form of a per se rule or a presumption of unconstitutionality. ${ }^{34}$ Rather, the test used in the context of "suspect classifications"3s such as racial classifications is very similar to that used by the Court in the context of fundamental freedoms. ${ }^{36}$ The finding of a racially-based classification seems to reverse the burden of proof with the proponent of the questioned conduct required to carry a "very heavy burden of justification"37 if the scrutinized conduct is to be saved from invalidation as contrary to the provisions of the fourteenth amendment. This test may be termed the "necessity test." As it was described in another context:

There is involved here an exercise of the state police power which trenches upon the constitutionally protected freedom from invidious official discrimination based on race. Such a law, even though enacted pursuant to a valid state interest, bears a heavy burden of justification . . . and will be upheld only if is necessary, and not merely rationally related, to the accomplishment of a permissible state policy. ${ }^{38}$

Establishing that the plans are racially based is admittedly a difficult task, since statements indicating racial desires are seldom if ever voluntarily and openly made by those charged with official responsibility. Relevant direct proof, if available, may be presented at the trial court level to establish the racial desires behind the use of the sex separation device. Appellate courts have taken judicial notice of the patterns of social behavior between the races, ${ }^{39}$ and judges have even been known to express their opinions on the matter. ${ }^{40}$ There seems

33 The summary invalidation without a showing of harm might have been ordered simply because no justification was demonstrated.

34 See, e.g., Loving v. Virginia, 388 U.S. 1 (1967); McLaughlin v. Florida, 379 U.S. 184 (1964).

35 See note 30 supra.

36 See text following note 130 infra.

37 Loving v. Virginia, 388 U.S. 1, 9 (1967).

38 McLaughlin v. Florida, 379 U.S. 184, 196 (1964) (emphasis added). See also Loving v. Virginia, 388 U.S. 1, 9 (1967); NAACP v. Button, 371 U.S. 415, 438-9 (1963); cf. Harper v. Virginia Bd. of Elections, 383 U.S. 663,668 (1966).

39 See, e.g., Meredith v. Fair, 298 F.2d 696, 701 (5th Cir. 1962); Funt v. Arnold, 172 F. Supp. 847, 856 (N.D. Ga. 1959).

40 Almighty God created the races white, black, yellow, malay and red, and he placed them on separate continents. And but for the intereference with his ar- 
to be a prevailing tendency to scrutinize carefully conduct and classifications in areas where racial problems have been involved and to imply a racial purpose or motive to suspicious conduct even when one cannot be adduced by direct proof. Courts seem willing to consider conduct in the context in which it appears, taking into account the habits and attitudes of those involved. ${ }^{41}$ Relevant here is the fact that the sex separation scheme is a new device not previously used in the particular educational systems in question ${ }^{42}$-a device which has been abandoned as an educational tool even by some of its staunchest supporters. ${ }^{43}$ The use of a novel device is rendered even more suspicious when it follows in the wake of repeated efforts to secure equal rights for blacks, efforts which have met with numerous obstacles. ${ }^{44}$

It should be noted that courts have even been willing to invalidate, absent sufficient justification, conduct which has been found-by direct proof or implication - to have only a partial racial basis. For instance, requirements that applicants to unions, ${ }^{45}$ universities, ${ }^{46}$ or professional societies ${ }^{47}$ furnish recommendations from present members of the organization or be referred by them may serve a valid purpose-screening of applicants by the old members. They may, however, be requirements which are intended to keep minority group applicants from membership. Despite a partial valid purpose, the conduct may be unconstitutional because of a partial racial purpose, and

rangement there would be no cause for such [inter]marriages. The fact that he separated the races shows that he did not intend for the races to mix.

An unknown Virginia trial court judge cited in Loving v. Virginia, 388 U.S. 1, 3 (1967). See also Hayes v. Crutcher, 108 F. Supp. 582, 585 (M.D. Tenn. 1952); Florida ex rel. Hawkins v. Bd. of Control, 83 So. 2d 20, 27-28 (Fla. 1955) (Terrell, J. concurring).

41 See, e.g., NAACP v. Button, 371 U.S. 415, 435-6 (1963); Lane v. Wilson, 307 U.S. 268, 276-7 (1939); United States v. Louisiana, 225 F. Supp. 353, 362-81 (E.D. La. 1963), aff'd, 380 U.S. 145 (1965); Hall v. St. Helena Parish, 197 F. Supp. 649, 651-2 (E.D. La. 1961), aff'd, 368 U.S. 515 (1962). See note 44 infra.

42 Cf. Hawkins v. North Carolina Dental Soc'y, 355 F.2d 718, 720-2 (4th Cir. 1966); United States v. Louisiana, 225 F. Supp. 353, 386 (E.D. La. 1963), aff d, 380 U.S. 145 (1965). See also Moore v. Tangipahoa Parish, 304 F. Supp. 244, 249 (E.D. La. 1969).

43 See N.Y. Times, Nov. 15, 1968, at I (Yale to admit undergraduate women); N.Y. Times, Nov. 15, 1968, at 34 (Vassar will admit men); N.Y. Times, Oct. 6, 1968, at 8 (Sarah Lawrence will admit men); N.Y. Times, Oct. 6, 1968, at 8 (Franklin \& Marshall, Kenyon, University of the South, and the College of Arts and Sciences of Georgetown will admit women); N.Y. Times, Sept. 25, 1968, at 32 (Choate will merge with Rosemary Hall). See also Moore v. Tangipahoa Parish, 304 F. Supp. 244, 249 (E.D. La. 1969).

44 "Innumerable cases have clearly established the principle that under circumstances ... where a history of racial discrimination exists, the burden of proof has been thrown upon the party having the power to produce the facts." Chambers v. Hendersonville Bd. of Educ., 364 F.2d 189, 192 (4th Cir. 1966). See note 41 supra.

45 See, e.g., Local 53 v. Vogler, 407 F.2d 1047, 1054 (5th Cir. 1969).

46 See, e.g., Meredith v. Fair, 298 F.2d 696 (5th Cir. 1962).

47 See, e.g., Hawkins v. North Carolina Dental Soc'y, 355 F.2d 718 (4th Cir. 1966). 
the organization "cannot salvage the invalidity of [the] requirement by convincing ... [the court] that it did not arise at least in part from racial bases." 48

As applied to the case at hand, if the use of the sex separation scheme is found-by direct proof or implication by the court-to be attributable totally or in part to a desire to keep opposite-sex members of the two races apart, the school board will be required to sustain a very heavy burden of justification, even higher than that normally required to justify a plan, because of the existence of a racially discriminatory motive for the plan.

\section{B. Racial Discrimination from Effect}

As an alternative to the direct finding of a racially discriminatory motive or purpose as a method of challenging conduct by the state as contrary to the equal protection requirements of the fourteenth amendment, conduct may be invalidated because of its effect. ${ }^{49}$ In particular, if the use of sex separation in school desegregation plans, however innocuous it may appear, has racially discriminatory effects, the plans will be held unconstitutional. One effect of the use of sex separation is clearly the separation of black boys from white girls and white boys from black girls. If it is determined that this situation results in a denial of equal educational opportunities, ${ }^{50}$ the sex separation may be unconstitutional because of its racially discriminatory effect, whether or not this discrimination is a conscious purpose of the scheme.

Before engaging in any inquiry into the racially discriminatory effects which may result from a system of sex separation in a racially mixed school system, two initial presumptions must be stated. First, it must be taken as a generally accepted principle of modern education that schools should be free of avoidable detriments in the form of racial discrimination. This would seem to be the clear mandate of Brown as well as the view of most educators. ${ }^{51}$ Second, any assess-

48 Local 53 v. Vogler, 407 F.2d 1047, 1054 (5th Gir. 1969). See Griffin v. County School Bd., 377 U.S. 218, 231 (1964).

49 See, e.g., Monroe v. Bd. of Comm'rs, 391 U.S. 450, 458 (1968); Brown v. Bd. of Educ., 347 U.S. 483 (1954); Henry v. Clarksdale, 409 F.2d 682, 688 (5th Cir. 1969); Green v. School Bd., 304 F.2d 118, 122 (4th Cir. 1962); Northcross v. Bd, of Educ., 302 F.2d 818, 823-4 (6th Cir.), cert. denied, 370 U.S. 944 (1962); Norwood v. Tucker, 287 F.2d 798 (8th Cir. 1961); cf. NAACP v. Button, 371 U.S. 415, 435-6 (1963); Gomillion v. Lightfoot, 364 U.S. 339, 346-8 (1960); Yick Wo v. Hopkins, 118 U.S. 356, 373-4 (1886); United States v. Louisiana, 225 F. Supp. 353, 362-3 (E.D. La. 1963), aff'd, 380 U.S. 145 (1965); Hall v. St. Helena Parish, 197 F. Supp. 649, 652 (E.D. La. 1961), aff'd, 368 U.S. 515 (1965).

50 See text at notes 57.87 infra.

$51[\mathrm{t} t$ is the business of the school environment to eliminate, so far as possible, the unworthy features of the existing environment from influence upon mental habitudes. It establishes a purified medium of action. Selection aims not only at sim- 
ment of the harmful effects engendered by a particular desegregation plan on the individuals involved necessarily is difficult to quantify and involves a great degree of uncertainty. ${ }^{62}$ It is the duty of the courts to examine in depth the possible effects of a plan in determining whether it eliminates the inequalities forbidden by Brown..$^{53}$

The harms inherent in a racially separated school system are identified and explored in Brown and further illuminated by two cases cited therein. ${ }^{54}$ Although the harms generated by a system of racial segregation are interrelated, the harms may be conveniently identified for the purpose of discussion as (1) the psychological harm, (2) the educational harm, and (3) the social harm. ${ }^{55} \mathrm{~A}$ search for the detriments inherent in a sex separation scheme begins most profitably with a consideration of the applicability of the harms identified in Brown to the sex separation scheme. ${ }^{56}$

plifying but at weeding out what is undesirable. Every society gets encumbered with what is trivial, with dead wood from the past, and with what is positively perverse. The school has the duty of omitting such things from the environment which it supplies, and thereby doing what it can to counteract their influence in the ordinary social environment. By selecting the best for its exclusive use, it strives to reinforce the power of this best. As a society becomes more enlightened, it realizes that it is responsible not to transmit and conserve the whole of its existing achievements, but only such as make for a better future society. The school is its chief agency for the accomplishment of this end. . . [ ] $\mathrm{t}$ is the office of the school environment to balance the various elements in the social environment, and to see to it that each individual gets an opportunity to escape from the limitations of the social group in which he was born, and to come into living contact with a broader environment.

J. Dewey, Democracy AND Education 24 (1936).

52 Fiss, Racial Imbalance in the Public Schools: The Constitutional Concepts, 78 HARv. L. REv. 564, 595-6 (1965); accord, Black, The Lawfulness of the Segregation Decisions, 69 YALE L.J. 421, 428 (1960). See McLaurin v. Oklahoma, 339 U.S. 637 (1950); Sweatt v. Painter, 339 U.S. 629 (1950); Brown v. Bd. of Educ., 347 U.S. 483 (1954).

53 Fiss, supra note 52 , at 588.

54 McLaurin v. Oklahoma, 339 U.S. 637 (1950); Sweatt v. Painter, 339 U.S. 629 (1950).

55 Fiss, supra note 52, at 568-70.

56 The harmful effects of segregation, and particularly the psychological effects, have been the subject of much discussion. In Brown, the Supreme Court used the authorities listed in the widely-discussed "footnote 11 " to support their strongest statements about the effects of segregation. See Brown v. Bd. of Educ., 347 U.S. 483, 494-5 (1954). The Court's use of the authorities in footnote 11 to support their conclusions about the harmful effects of segregation has been criticized. Perhaps the best known criticism is Cahn, Jurisprudence, 30 N.Y.U.L. REv. 150 (1955). Cahn concentrates his criticism on the research of Kenneth B. Clark whose work was cited by the Court in Brown. Id. at 159-68. It is interesting to note that Cahn only challenges the methods used by Clark but never his conclusions and, in fact, describes Clark's conclusions about the effects of segregation as "a fact of common experience." Id. at 160. Even Cahn's criticism of Clark's methods is prefaced by a caveat"my reaction may be due to a lack of technical training in scientific psychology and psychological testing." Id. at 161. It appears that even the expert witnesses called by the defense to testify in Brown "admitted, in one way or another, that racial segregation in the schools does injure Negro children's personalities." Id. at 160 (emphasis in original). This comment will proceed on the assumption that, on the best evidence available, those harms identified in Brown are the actual effects of racial segregation. 
1. The Psychological Harm. Separation of students in the public school system solely on the basis of race "generates a feeling of inferiority as to [the black students'] status in the community that may affect their hearts and minds in a way unlikely ever to be undone." 57 As recognized in Brown, segregation by race is a source of frustration, feelings of inferiority, humiliation, and distortion to the minority group. ${ }^{58}$ These detrimental effects are compounded when the segregation has the sanction of law; for the policy of separation is usually interpreted as denoting the inferiority of the black child. ${ }^{59}$

[E]nforced segregation gives official recognition and sanction to [ordinary, private expressions of prejudice], and thereby enhances the effects of the latter in creating the awareness of social status differences and feelings of inferiority. The child who, for example, is compelled to attend a segregated school may be able to cope with ordinary expressions of prejudice by regarding the prejudiced person as evil or misguided; but he cannot readily cope with symbols of authority, the full force of the authority of the State-the school or the school board, in this instance-in the same manner. Given both the ordinary expression of prejudice and the school's policy of segregation, the former takes on greater force and seemingly becomes an official expression of the latter. ${ }^{60}$

If blacks perceive in a sex separation scheme a desire to keep black boys from white girls and white boys from black girls, ${ }^{61}$ it can be argued that a scheme of sex separation will produce psychological harms similar to those inherent in race segregation. Black students, knowing,

57 Brown v. Bd. of Educ., 347 U.S. 483, 494 (1954). See also Packinghouse Workers v. NLRB, 416 F.2d 1126, 1136-8 (D.C. Cir. 1969).

$88 \mathrm{~K}$. Clark, Prejudice and Your Child 39 (2d ed. 1963). See E. Frazter, The Negro in the United States 674-81 (1949); Personality in the Making 136-40 (H. Witmer \& R. Kotinsky eds. 1952); Brameld, Educational Costs, in Discrimination and Natronal WeLFARE 45-46 (R. Maciver ed. 1949); Chein, What are the Psychological Effects of Segregation Under Conditions of Equal Facilities?, 3 INT'L J. OPINION AND ATTrrude REs. 229 (1949); Deutscher \& Chein, The Psychological Effects of Enforced Segregation: A Survey of Social Science Opinion, 26 J. PsychoL. 259 (1948); Milner, Some Hypotheses Concerning the Influence of Segregation on Negro Personality Development, 16 PsYchiATRY $291-7$ (1953). See generally MYRDAL, supra note 25, at 640-63. Contra, Plessy v. Ferguson, 163 U.S. 537, 551 (1896).

69 Brown v. Bd. of Educ., 347 U.S. 483, 494 (1954). See CLARK, supra note 58, at 63.

60 The Effects of Segregation and the Consequences of Desegregation: A Social Science Statement, 37 MINN. L. REv. 427, 433 (1953) [hereinafter cited as Brown Appendix]. This document, drafted and signed by 32 sociologists, anthropologists, psychologists, and psychiatrists who have worked in the field of American race relations, was an appendix to the Appellants' Brief in Brown.

61 See pp. 300-1 supra. 
assuming, or even suspecting the purpose of the school boards-to keep members of one race from opposite-sex members of the other race-may experience the same or similar psychological effects as those generated by outright race separation. Surely they can glean an awareness of the school board's desires as a result of their former experiences with segregation and with the attitudes of the dominant whites toward school desegregation. Moreover, this scheme, like race segregation, has the sanction of the law in the form of school board approval thus lending governmental prestige to the sex separation analogous to the governmental approval found in race segregation.

2. The Educational Harm. Closely related to the psychological harm resulting from enforced racial segregation are the educational harms. The Court in Brown recognized this aspect of the problem:

A sense of inferiority affects the motivation of a child to learn. Segregation with the sanction of law, therefore, has a tendency to [retard] the educational and mental development of Negro children and to deprive them of some of the benefits they would receive in a racial[ly] integrated school system. ${ }^{62}$

The educational success of a student is closely related to his psychological state. Segregation causes a reaction of defeatism and a lowering of personal ambitions. ${ }^{63}$ This is, in turn, reflected in a lowering of pupil morale and educational aspirations with the ultimate result being an impairment of "the ability of the child to profit from the educational opportunities provided him." 64 If one accepts the proposition that black children are psychologically harmed by the sex separation scheme, ${ }^{65}$ it is a corollary that educational harms will likewise result. The two seem to be intimately intertwined, and the proof of one would in all probability, as in Brown, be the proof of the other. ${ }^{68}$

There is yet another aspect to the educational harms inherent in racial segregation which must be considered in the context of sex separation. Brown, and two cases decided four years earlier and cited with approval in the Court's opinion, recognized that education which excluded "a substantial and significant segment of society" 67 from the educational atmosphere meant inferior education. In Sweatt $v$.

62347 U.S. at 494 (1954) (emphasis added).

63 See CLARK, supra note 58, at 37-65; Brown Appendix, supra note 60, at 430; Fiss, supra note 52, at 568-9. See also Packinghouse Workers v. NLRB, 416 F.2d 126, 136-8 (D.C. Cir. 1969).

64 Brown Appendix, supra note 60, at 430 .

65 See pp. 307-8 supra.

66 See Brown v. Bd. of Educ., 347 U.S. 483,494 (1954).

67 Sweatt v. Painter, 339 U.S. 629, 634 (1950). 
Painter ${ }^{68}$ the petitioner was denied admission to the state-supported University of Texas Law School because of a state law forbidding admission of blacks to that school. Although he was offered, but refused, enrollment in a separate law school newly established by the state for blacks, the Court held, mainly on the basis of an inequality of facilities in violation of the "separate but equal" doctrine, ${ }^{69}$ that the equal protection clause "requires that petitioner be admitted to the University of Texas Law School."70 The Court's reasoning in finding an inequality in education is significant and was incorporated into Brown. After recognizing that a racially segregated school denied the student "those qualities which are incapable of objective measurement but which make for greatness in a law school," 71 the Court concluded that, absent "a substantial and significant segment of society [i.e. whites] the education offered the segregated black student was not equal to that which he would receive if admitted to the all-white school. ${ }^{72}$ In McLaurin v. Oklahoma, ${ }^{73}$ a black citizen of Oklahoma was admitted to the state-supported graduate school of the University of Oklahoma. He was, pursuant to a state law requiring that black students in higher education be educated on a segregated basis, assigned to a seat in each classroom in a row specified for black students and assigned to special tables in the library and cafeteria. As in Sweatt, the conduct was declared unconstitutional as a denial of equal protection of the laws. The Court stated: "Such restrictions impair and inhibit his ability to study, to engage in discussion and exchange views with other students, and, in general to learn his profession." "74

The Court in Brown found that the educational benefits, which are derived from learning in a racially integrated context, were absent in the case of race separation and based its mandate, at least in part; upon the absence of "the interplay of ideas and the exchange of views"75 in race segregation which had been similarly found missing in Sweatt and McLaurin. Just as students can gain new ideas, different approaches to subject matter, and varying attitudes from education in a racially mixed school, exposure to the opposite-sex members of one's own race and the other race in the learning context

\footnotetext{
68339 U.S. 629 (1950).

69 See Plessy v. Ferguson, 163 U.S. 537 (1896).

70 Sweatt v. Painter, 339 U.S. 629, 634 (1950).

71 Id. at 634 .

72 Id.

73389 U.S. 687 (1950).

74 Id. at 641. See Fiss, supra note 52, at 569-70.

75 Sweatt v. Painter, 339 U.S. 629,634 (1950). See Fiss, supra note 52, at 569-70. See also Rogers v. Paul, 382 U.S. 198 (1965); Brameld, supra note 58, at 45.
} 
may result in the same educational benefits, and these benefits may be denied by a sex separation scheme. ${ }^{76}$

3. The Social Harm. Overlapping the psychological and educational harms, the existence of the social harms in racial separation was clearly enunciated in McLaurin and approved in Brown: ${ }^{77}$

The removal of the state restrictions will not necessarily abate individual and group predilections, prejudices and choices. But at the very least, the state will not be depriving appellant of his opportunity to secure acceptance by his fellow students on his own merits. ${ }^{78}$

Segregation imposes upon the individual a distorted sense of the social realities. ${ }^{79}$ Not only does the perpetuation of social barriers lead to a blockage of communication and interaction between the racial groups which in turn increases mutual suspicions, distrust, and hostility, but it also reinforces stereotypes and perpetuates negative attitudes toward the members of the other group. ${ }^{80}$ Also, social barriers may mean educational detriments in the sense of lost opportunities for contact with members of the dominant group. ${ }^{81}$ Courts have taken judicial notice of these social barriers between the races, ${ }^{82}$ and the Court in Brown, when read with McLaurin, seems to recognize the perpetuation of the social barriers between the races as a harm resulting from racial segregation. ${ }^{83}$

If social barriers are perpetuated by race separation, they may be analogously perpetuated in a scheme which, although seemingly neu-

76 See Dale, Co-Education: The Verdict of Experience-Part II.A Qualitative Approach, 35 BRIT. J. OF Evuc. Psychol. 195, 196-7 (1965); Taylor, Coeducation for the Colleges: Why? How? and When?, 52 LIBERAL Educ. 271 (1966).

If the sex segregated high schools were to result in an inferior educational opportunity for the high school students, then this would merely serve to accentuate the handicap of the disadvantaged education that the Negro children have previously received.

McFerren v. County Board of Educ. of Fayette County, Civil No. C-65-136 (W.D. Tenn. 1969) (United States Government's Objections to Plan).

77347 U.S. at 493 (1954).

78 McLaurin v. Oklahoma, 339 U.S. 637, $641-2$ (1950).

79 See Brown Appendix, supra note 60, at 432; Dale, supra note 76, at 197; Kolesnik, Should Students Be Separated by Sex? 63 CATH. Educ. Rev. 73, 79 (1965); Taylor, supra note 76, at 271; cf. N. McCluskeY, Gatholic ViewPoint on Education 98 (1962).

80 See Clark, supra note 58, at 39; T. Newcomb, Social Psychology 572-615 (1950); E. Suchman, J. Dean, \& R. Williams, Jr., Desegregation: Some Propositions and Research SugGestions 11-20, 47-56 (1958); Brameld, supra note 58, at 46-47; Brown Appendix, supra note 60, at 432; Milner, supra note 58, at 291-7.

81 See Sweatt v. Painter, 339 U.S. 629, 634 (1950).

82 See, e.g., Meredith v. Fair, 298 F.2d 696, 701 (5th Cir. 1962); Hunt v. Annold, 172 F. Supp. 847, 856 (N.D. Ga. 1959).

83 Brown v. Bd. of Educ., 347 U.S. 483, 493 (1954). 
tral on its face, separates black boys from white girls and white boys from black girls. Viewed in this light, sex separation may lead to a blockage of communication, intensifying misunderstandings, distrust, and, most importantly stereotypes-the very harms identified in Brown.

Attempts, by the courts, to regulate social barriers between oppositesex members of the white and black races and to interfere with manifestations of those barriers, such as the sex separation scheme, might be seen as an attempt to regulate attitudes. In another context, it was said:

Legislation is powerless to eradicate racial instincts or to abolish distinctions based upon physical differences, and the attempt to do so can only result in accentuating the difficulties of the present situation. If the civil and political rights of both races be equal one cannot be inferior to the other civilly or politically. If one race be inferior to the other socially, the Constitution of the United States cannot put them upon the same plane. ${ }^{84}$

Not only has Plessy $v$. Ferguson, ${ }^{85}$ the source of this argument and the "separate but equal" doctrine, been thoroughly discredited, but it may be said that attempting to reach attitudes which forbid contacts between black men and white women and white men and black women is no longer beyond the powers nor outside the duties of the courts. In satisfying the requirement of dismantling a still-functioning dual educational system and of converting "to a unitary non-racial system-lock, stock, and barrel," 86 school boards may be permitted and even required to dispel attitudes such as these. The import of Brown is clear:

School boards ... operating state-compelled dual systems were . . . clearly charged with the affirmative duty to take whatever steps might be necessary to convert to a unitary system in which racial discrimination would be eliminated root and branch..$^{87}$

\section{Sex Separation as Sex Discrimination}

Whether or not the creation of separate schools for boys and girls in a school desegregation plan is found to be racially based or to have

84 Plessy v. Ferguson, 163 U.S. 537, $551-2$ (1896).

85163 U.S. 537 (1896).

88 United States v. Jefferson County, 372 F.2d 836, 878 (5th Cir. 1966), adopted en banc, 380 F.2d 385 (5th Cir.), cert. denied, 389 U.S. 840 (1967). See United States v. Montgomery County, 395 U.S. 225, 230 (1969); cf. Louisiana v. United States, 380 U.S. 145, 154 (1965). See also Griffin v. County School Bd., 377 U.S. 218, 232-4 (1964).

87 Green v. New Kent County, 391 U.S. 430, 437-8 (1968) (emphasis added). 
a racially discriminatory effect, and is thereby found to be a mere facade for racial discrimination, the sex separation scheme results in a clear classification-boys and girls placed in their educational environment solely on the basis of their sex. Sex separation may be viewed as a form of sex discrimination which, by separating female students as a class and denying them the benefits of equal educational opportunities, may be contrary to the fourteenth amendment's equal protection requirements. ${ }^{88}$

The status and problems of the woman in America present a curious parallel to those of the black. Women, like blacks, are characterized by a high social visibility expressed in physical appearance, dress, and patterns of behavior setting them apart as a distinct "class." 89 Besides a high degree of visibility, women and blacks also share the dubious distinction of being the victims of very similar arguments used by the dominant group to justify the inferior position accorded

88 The fourteenth amendment forbids classifications by the states or their agents, discriminating against some and favoring others, which do not bear a reasonable relationship to the promotion of a valid public purpose. Yick Wo v. Hopkins, 118 U.S. 356 (1886); cf. Barbier v. Connolly, 113 U.S. 27, 32 (1885).

The discussion of sex separation in school desegregation plans may be viewed as a bifurcated problem. The plans may be viewed as racially discriminatory conduct. See text at notes 25-87 supra. By that theory, the black children are the "minority group" to be considered as victims of any inherent harms. However, the plans may also be viewed as classification on the basis of sex. Although, as will be discussed below, boys and girls are both classified, for the purposes of this discussion, girls, the numerical minority, will be considered the "minority group."

Including women as a class under the fourteenth amendment's equal protection requirements would seem to necessitate a showing that (1) women are set apart as a class, (2) they are harmed in some way by this delineation, and (3) the classification is unjustified. See Hernandez v. Texas, 347 U.S. 475 (1954). As to the necessity of showing a "purpose" to discriminate, see Horowitz, Unseparate but Unequal-The Emerging Fourteenth Amendment Issue in Public School Education, 13 U.C.L.A.L. Rev. 1147, 1150-5 (1966). Recently, sex exclusion at the University of Virginia at Charlottesville was declared unconstitutional.

We hold ... that on the facts of this case these particular plaintiffs have been ... denied their constitutional right to an education equal with that offered men at Charlottesville and that such discrimination on the basis of sex violates the Equal Protection Clause of the Fourteenth Amendment.

Kirstein v. University of Virginia, Civil No. 220-69-R (E.D. Va. 1969) (unreported order of 3-judge panel-Feb. 6, 1970).

80 In every society there are at least two groups of people, besides the Negroes, who are characterized by high social visibility expressed in physical appearance, dress, and patterns of behavior, and who have been "suppressed." We refer to women and children. Their present status, as well as their history and their problems in society, reveal striking similarities to those of the Negroes.

MYrDAL, supra note 25, at 1073.

See A. Montagu, Man's Most Dangerous Myth: The Fallagy of Race 181 (4th ed. 1964); Crozier, Constitutionality of Discrimination Based on Sex, 15 B.U.L. REv. 723, 727-8 (1935); Hacker, Woman as a Minority Group, 30 Socral Forces 60, 65 (1951); Murray \& Eastwood, Jane Crow and the Law: Sex Discrimination and Title VII, 34 GEO. WASH. L. REV, 232, 233-5 (1965).' 
them, including inferior intelligence, scarcity of geniuses, freedom in instinctual gratifications, and emotionalism.90 Both groups were assigned a "place" in society, whether it be the field or the home, and were barred from education, suffrage, certain jobs, and political office. ${ }^{91}$ Most significantly, the actions of the dominant groups toward both blacks and women were thought to be in the best interest of the subordinate groups. ${ }^{92}$

The history of the separate treatment of women in the eyes of the law, or more properly the sex classification, begins with the Supreme Court decision in Muller $v$. Oregon.$^{93} \mathrm{~A} 1903$ Oregon statute, providing that no female shall work in certain establishments more than ten hours a day, was held not to be in violation of the fourteenth amendment and a valid exercise of the police power. However, the legislation was also sustained as a valid method of expressing the public interest in preserving "the well-being of the race" ${ }^{94}$ by protecting women's health needs and the exercise of her maternal function.

[S] he is properly placed in a class by herself, and legislation designed for her protection may be sustained, even when like legislation is not necessary for men and could not be sustained .... [H] physical structure and a proper discharge of her maternal function-having in view not merely her own health, but the well-being of the race-justify legislation to protect her from the greed as well as the passion of man. ${ }^{95}$

From this language has been extracted the principle that sex is a valid basis for classification, a principle which is often relied upon without regard to the purpose of the conduct involving sex classification or the reasonableness of the relationship between the use of the sex classification and that purpose. ${ }^{96}$ The language of Muller has been utilized in subsequent decisions to support such measures as a Michigan law preventing most females from becoming licensed bartenders, ${ }^{97}$ a Florida enactment excluding women from jury service unless they affirmatively

90 See Montagu, supra note 89, at 181, MYrdal, supra note 25, at 1077.

o1 Id.

92 Id.

93208 U.S. 412 (1908). On the history of the sex classification, see Murray \& Eastwood, supra note 89 , at $236-8$.

94 Muller v. Oregon, 208 U.S. 412,422 (1908).

95 Id.

96 L. Kanowitz, Constitutional Aspects of Sex-Based Discrimination, in WOMEN AND THE LAw 154 (1969); accord, Murray \& Eastwood, supra note 89, at 239.

97 Goesaert v. Cleary, 335 U,S, 464 (1948). 
volunteer to serve, ${ }^{98}$ exclusion of women from state-supported institutions in Texas, ${ }^{99}$ and a variety of other examples of sex classification..$^{100}$

It should be noted that the sex classification-unequal treatment of women in the eyes of the law-seems to be disappearing. ${ }^{101}$ However, women appear to remain the victims of discrimination based on sex, especially in the fields of education ${ }^{102}$ and employment, ${ }^{103}$ and language reminiscent of Muller still appears. ${ }^{104}$

Including women as a class under the equal protection clause of the fourteenth amendment will not be aided by a resort to the inconclusive legislative history of that amendment. ${ }^{105}$ It seems clear, however, that, whatever the history of the enactment of the amendment, the guarantees of the fourteenth amendment are not static and may well be found to apply to this class.

98 Hoyt v. Florida, 368 U.S. 57 (1961).

99 Alfred v. Heaton, 336 S.W.2d 251 (Tex. Civ. App.), cert. denied, 364 U.S. 517 (1960); Heaton v. Bristol, 317 S.W.2d 86 (Tex. Civ. App. 1958), cert. denied, 359 U.S. 230 (1959).

100 See, e.g., West Coast Hotel Co. v. Parrish, 300 U.S. 379 (1937); Radice v. New York, 264 U.S. 292 (1924); Bosley v. McLaughlin, 236 U.S. 385 (1915); Miller v. Wilson, 236 U.S. 373 (1915); Riley v. Massachusetts, 232 U.S. 671 (1914).

101 As a result of the Equal Pay Act of 1963, women are now entitled to equal payment for equal time worked, 29 U.S.C. $\S 206$ (d) (1964); "sex" was included along with race, color, religion, and national origin in the equal employment oportunity provisions of the Civil Rights Act of 1964, 42 U.S.C. $\$ 2000$ (e), et seq. (1964); as a result of presidential order, discrimination against women in federal employment is forbidden, U.S. CrviL Serv. Comm'n federal Personnel Manual ch. 713-6-713-8 (1963). See Abbott v. Mines, 411 F.2d 353, 355 (6th Cir. 1969); White v. Crook, 251 F. Supp. 401, 408-9 (N.D. Ala. 1966); Murray \& Eastwood, supra note 89, at 232-3.

102 Professional schools, such as architecture and medicine, apply quotas. Hacker, supra note 89 , at 62 . In the last thirty years, women have been receiving a decreasing proportion of master's degrees and doctorates resulting, to a great extent, from the unequal distribution of stipends and fellowships to women. On the Graduate School Payroll, Careers Today (Jan. 1969). See President's Comm. on the Status of Women, American WOMEN 11-13 (1963) [hereinafter cited as PresidenT's CoMm.].

103 The number of charges filed with the Equal Employment Opportunity Commission under Title VII have demonstrated that race and sex discrimination are by far the most prevalent forms of discrimination in employment. In fiscal 1966, for example, the charges filed with EEOC by category were: race or color $53.1 \%$; sex $34 \%$; unspecified $9.9 \%$; national origin 2.1\%; religion 1.4\%. EEOC Report of Compliance Activities, BNA FAIR Employment Practices 431:61. See Kanowitz, Sex-Based Discrimination in American Law III: Title VII of the 1964 Civil Rights Act and the Equal Pay Act of 1963, 20 Hastings L.J. 305 (1968).

104 Despite the enlightened emancipation of women from the restrictions and protections of bygone years, and their entry into many parts of community life formerly considered to be reserved to men, woman is still regarded as the center of home and family life. We cannot say that it is constitutionally impermissible for a State, acting in pursuit of the general welfare, to conclude that a woman should be relieved from the civic duty of jury service unless she herself determines that such service is consistent with her own special responsibilities.

Hoyt v. Florida, 368 U.S. 57, 61-62 (1961).

105 See Loving v. Virginia, 388 U.S. 1, 9-10 (1967); Brown v. Bd. of Educ, 347 U.S. 483,489 (1954). 
When the existence of a distinct class is demonstrated, and it is further shown that the laws, as written or as applied, single out that class for different treatment not based on some reasonable classification, the guarantees of the Constitution have been violated. The Fourteenth Amendment is not directed solely against discrimination due to a "two-class theory"- that is, based upon differences between "white" and Negro. ${ }^{106}$

The harms which are inflicted upon the female student may be best illustrated by again resorting to a parallel to the harms found in race separation. First, psychological effects similar to those found in race separation may also exist in sex separation. Although little reasearch has been done directly on sex segregation, no systematic empirical study. or theoretical article has asserted that a segregated human being benefits thereby. ${ }^{107}$ There is, moreover, persuasive evidence that the effects of involuntary segregation are not a function of the particular characteristics of the subordinate group, but rather these effects are generated by the characteristics of the segregation situation itself. ${ }^{108}$ Personality damage associated with segregation is found among all segregated children regardless of "racial, nationality, or religious background."100 In fact, it has been noted that women's overt reactions to sex discrimination are even stronger than those manifested by other minorities when faced with discrimination. ${ }^{110}$ Moreover, the conduct in the sex separation situation has the sanction of law in the form of school board approval thus lending governmental prestige to the sex distinction analogous to the governmental approval found in race segregation.111 In short, there is evidence pointing to the conclusion that the same psychological detriments, alleged to harm the segregated black, may also harm the separated female.

Second, if one accepts the proposition that female students are psychologically harmed by sex separation, it seems that educational harms will likely result also. ${ }^{112}$ As in the case of psychological effects, the educational harms associated with segregation seem not to be restricted to any particular group, social or economic, nor are they confined to any particular racial, nationality, or religious background. ${ }^{113}$ Once again,

106 Hernandez v. Texas, 347 U.S. 475,478 (1954). See Harper v. Virginia Bd. of

Elections, 383 U.S. 663, 668 (1966); Hoyt v. Florida, 368 U.S. 57, 59-60 (1961).

107 Clark, supra note 58, at 63.

$108 I d$.

109 Id. See Brown Appendix, supra note 60, at 430.

110 Hacker, supra note 89 , at 61 .

111 See text at notes 59-60 supra. See also Murray \& Eastwood, supra note 89, at 240.

But see Wechsler, supra note 31, at 33.

112 See p. 308 supra.

113 ClARR, supra note 58, at 63. See Brown Appendix, supra note 60, at 430 . 
the sex separation may affect the female, this time in retarding educational development, as race segregation affects the black. Of course, any educational benefits to be derived from a heterogeneous educational atmosphere are lost to the female when separated from her male contemporaries in the learning process. Finally, if social barriers are perpetuated by race separation, they are analogously perpetuated in sex separation; the sexes are kept apart resulting in an atmosphere which inadequately prepares one for the realities of social life in a world of two sexes. ${ }^{114}$

Although the use of the "necessity test" has been advocated in the context of sex classification, ${ }^{115}$ if the sex separation schemes are viewed -devoid of any racial overtones-as involving only a distinction based on sex, the test which will, in all probability, be employed will be the so-called "reasonable relation test."

[C]lassification cannot be made arbitrarily . . . . [but] must always rest upon some difference which bears a reasonable and just relation to the act in respect to which the classification is proposed ....116

Here, the objective is clearly equal educational opportunities, ${ }^{117}$ and the question will be: Does the sex separation bear a reasonable relation to the achievement of equal educational opportunities?

The Supreme Court has never found a law or administrative action based on a classification according to sex to be unconstitutional. ${ }^{118}$ Yet, it may be that sex separation in school desegregation plans-which sets women apart as a class without any apparent justification ${ }^{119}$-presents an ideal situation for a challenge to the validily and viability of $\mathrm{Muller}$ and its disciples.

114 See Dale, supra note 76, at 197; Kolesnik, supra note 79, at 79; Taylor, supra note 76 , at 271 .

115 While the Supreme Court has not explicitly determined whether equal protection rights of women should be tested by this rigid standard, it is difficult to find any reason why adult women, as one of the specific groups that compose humanity, should have a lesser measure of protection than a racial group.

United States ex rel. Robinson v. York, 281 F. Supp. 8, 14 (D. Conn. 1968).

116 Gulf, Colorado \& Santa Fe Ry. v. Ellis, I65 U.S. 150, 155 (1897). See McGowan v. Maryland, 366 U.S. 420, $425-6$ (1961); Hernandez v. Texas, 347 U.S. 475, 478 (1954); Skinner v. Oklahoma, 316 U.S. 535, 541-3 (1942). See also Fiss, supra note 52, at 579.

117 Brown v. Bd. of Educ., 347 U.S. 483 (1954).

118 And, it further appearing to the Court that this is the first federal suit of which we are aware brought to test the constitutionality of enforced separation of the sexes in a state educational institution, and that the question of constitutionality is novel and difficult ....

Kirstein v. University of Virginia, Givil No. 220-69-R (E.D. Va. 1969) (unreported order of 3-judge panel, Sept. 30, 1969). See note 120 infra.

119 See pp: 219-26 infra. 
Early and definitive court pronouncement, particularly by the U.S. Supreme Court, is urgently needed with regard to the validity under the 5th and 14th amendments of laws and official practices discriminating against women, to the end that the principle of equality become firmly established in constitutional doctrine. ${ }^{120}$

\section{Sex Separation as Limiting Freedom of Association}

Sex separation in school desegregation plans may be viewed as an unconstitutional restriction of the freedom of association, ${ }^{121}$ an approach advanced by Professor Wechsler of Columbia University Law School:

For me, assuming equal facilities, the question posed by state-enforced segregation is not one of discrimination at all. Its human and its constitutional dimensions lie entirely elsewhere, in the denial by the state of freedom to associate, a denial that impinges in the same way on any groups or races that may be involved..$^{122}$

This freedom of association, carried from the first amendment to the states through the fourteenth, ${ }^{123}$ may be violated by the separation of students from the opposite sex of his own race and from opposite-sex members of the other race. School authorities, as agents of the state, may not violate the basic constitutional right of freedom to associate in the performance of their ministerial function regarding schools any more than they can deny equal educational opportunities. ${ }^{124}$

120 President's Comm., supra note 102, at 45; accord, Murray \& Eastwood, supra note 89 , at 238. If the sex separation schemes are judged invalid, viewing the case simply as sex classification in the public schools devoid of any racial overtones, the decision could have broad ramifications for all separate education in public school systems. In the field of education, the sex separation in New York public schools has been challenged, and a settlement reached, by a girl seeking admission to a previously all-boys high school. N.Y. Times, May 9, 1969, at 21. The exclusion of women from the undergraduate roles at the University of Virginia at Charlottesville has been successfully challenged. Kirstein v. University of Virginia, Civil No. 220-69-R (E.D. Va. 1969) (unreported order of 3-judge panel, Feb. 6, 1970).

121 "The association of people is not mentioned in the Constitution nor in the Bill of Rights ... . Yet, the First Amendment has been construed to include certain of these rights." Griswold v. Connecticut, 381 U.S. 479, 482 (1965).

122 Wechsler, supra note 31, at 34. See Plessy v. Ferguson, I63 U.S. 537, 557 (1896) (Harlan, J. dissenting).

123 See McLaughlin v. Florida, 379 U.S. 184, I97 (1964) (Harlan, J. concurring); NAACP v. Button, 371 U.S. 415, 428 (1963); NAACP v. Alabama, 357 U.S. 449, 460 (1958).

124 See Epperson v. Arkansas, 393 U.S. 97, 107 (1968). See also Griswold v. Connecticut, 381 U.S. 479, $481-6$ (1965); Barenblatt v. United States, 360 U.S. 109 (1959); Sweezy v. New Hampshire, 354 U.S. 234 (1957); Meyer v. Nebraska, 262 U.S. 390 (1923). 
The Supreme Court has recently decided two important cases on interracial association which are relevant to this consideration of sex separation schemes in school desegregation plans as limitations on the freedom of association. In McLaughlin v. Florida, ${ }^{125}$ the Court declared unconstitutional a Florida criminal statute prohibiting an unmarried interracial couple from habitually living in and occupying the same room in the nighttime when no other statute penalized precisely the same conduct when engaged in by members of the same race. In Loving $v$. Virginia, ${ }^{126}$ the Court held that the Virginia anti-miscegenation law was a denial of equal protection of the laws and, thus, unconstitutional as a violation of the fourteenth amendment. By declaring prohibitions on interracial cohabitation and miscegenation to be unconstitutional, the Court is arguably protecting the fundamental freedom of association when it is denied along racial lines.

If a desire to keep opposite-sex members of the two races apart is found in the context of sex separation, ${ }^{127}$ the plans may have as their purpose separation of the races similar to the separation now declared unconstitutional. Whatever their purpose, the schemes might be said to have the effect of extending the now unconstitutional bans on interracial contacts. "The [fourteenth] Amendment nullifies sophisticated as well as simple-minded modes of discrimination."128 The schemes may be seen as another "ingeniusly or ingenuously" 128 contrived method of reaching a prohibited result through conduct which appears neutral on its face. "It is a familiar principle that conduct which in usual situations the law protects may become unlawful when part of a scheme to reach a prohibited result."130

If the use by a school board of sex separation in school desegregation plans is viewed as conduct infringing upon the fundamental freedom of association guaranteed by the fourteenth amendment, the test which the court will apply will in all probability be that traditionally used in evaluation of conduct affecting fundamental interests. The test-which may, for convenience, be called "strict scrutiny"-is probably best explained by the words of the Court:

These freedoms are delicate and vulnerable, as well as precious in our society. The threat of sanctions may deter their exercise almost as potently as the actual application of sanctions. ... Because the First Amendment freedoms need breathing space

125379 U.S. 184 (1964).

126388 U.S. 1 (1967).

127 See pp. 300-1 supra.

128 Lane v. Wilson, 307 U.S. 268, 275 (1939).

129 Smith v. Texas, 311 U.S. 128, 132 (1940).

130 Miller v. Milwaukee, 272 U.S. 713, 715 (1927). 
to survive, government may regulate in the area only with narrow specificity. ${ }^{131}$

Although valid reasons for state interference with the freedom of association may exist, ${ }^{132}$ surely any encroachment upon a fundamental freedom must carry with it a heavy burden of justification as the Court has declared in at least one case: "We do not now conceive of any circumstances wherein a state interest would justify infringement of rights in these fields." 133

\section{The Defense of Sex Separation}

Since it seems that by whichever test-"necessity,"134 "reasonable relation,"135 or "strict scrutiny"136 - the courts choose to evaluate the constitutionality of sex separation in school desegregation plans, justifications of such plans will continue to be relevant, the next inquiry must concern possible defenses for sex separation. It is important to recall that in the context of a school desegregation plan school boards must satisfy a heavy burden of proof in persuading the courts that sex separation meets the requirements of Brown ${ }^{137}$ This discussion will include those defenses which have actually been advanced by school boards defending plans before district courts as well as those which might be advanced in the future.

\section{A. The Equal Application Defense}

The first defense which has been advanced for sex separation is the familiar claim that equal application is a valid defense for an act involving classification. Those who support this view argue that a system of sex separation such as that proposed by the school boards in the South affects whites as much as it affects blacks and affects boys as much as it affects girls. Just as detrimental psychological effects may be

131 NAACP v. Button, 371 U.S. 415, 433 (1963); see NAACP v. Alabama, 357 U.S. 449, 460-1 (1958).

132 See Bates v. Little Rock, 361 U.S. 516, 524 (1960); NAACP v. Alabama, 357 U.S. 449, 463-6 (1958). The educational process is replete with examples of limitations on the freedom to associate. For instance, often a student may not be allowed to select the particular public school which he wishes to attend even if his friends attend that school; nor may he select classes with his friends when the school employs a "tracking system." Unfortunately, a clear principle delineating the permissible limitations on the freedom to associate in the school context has not arisen from the cases.

133 Sweezy v. New Hampshire, 354 U.S. 231, 251 (1957); see NAACP v. Alabama, 357 U.S. 449, 460-1 (1958).

134 See text at notes $29-38$ supra.

135 See text at notes 115-6 supra.

136 See text following note 130 supra.

137 See pp. 298-300 supra. 
produced in the subordinate group, blacks or women, ${ }^{138}$ segregation affects the dominant group. ${ }^{139}$ Although it may be said that black boys are kept from white girls, so too are white boys kept from white girls with the resulting educational consequences and social barriers. ${ }^{140}$

If racial discrimination is found in sex separation schemes, through a finding of a racial basis or racially discriminatory effects, the fact of equal application, reflecting a regression to the now discredited doctrine of "separate but equal," would seem to be irrelevant. "[T]he fact of equal application does not immunize the statute from the very heavy burden of justification which the Fourteenth Amendment has traditionally required of state statutes drawn according to race."141 If the problem is viewed as an instance of pure classification based on sex, absent a racial element, at least in the case of a statute, equal application is only a preliminary inquiry. "Judicial inquiry under the Equal Protection Clause ... does not end with a showing of equal application among the members of the class defined by the legislation. The courts must reach and determine the question whether the classifications drawn in a statute are reasonable in light of its purpose . . .."142 If the conduct is viewed simply as sex classification, the equal application does not serve as a defense but rather leads back to the "reasonable relation test" and leaves the question unanswered. Of course, it is an anomaly to assert that equal application justifies encroachment upon a fundamental freedom.

\section{B. The Temporary Step Defense}

Another justification which has been advanced in defense of a plan of sex separation runs as follows: "The school board offers this proposal only as a transitory measure designed to ease the conversion to a unitary system." ${ }^{143}$ Admitting that race and racial attitudes are being taken into account in the formulation of the plan, the proponents of this view maintain that integrating the races by sex will help dispel many of the

138 See pp. 307-8 and text following note 106 supra.

139 See CrARK, supra note 58, at 40; MYRDAL, supra note 25, at 643-4; Black, supra note 52 , at 428 , Brameld, supra note 58 , at 44 .

140 See pp. 308-11 supra.

141 Loving v. Virginia, 388 U.S. 1, 9 (1967).

142 McLaughlin v. Florida, 379 U.S. 184, 191 (1964).

143 Smith v. St. Tammany Parish, 302 F. Supp. 106, 108 (E.D. La. 1969).

In order to obtain better community acceptance of such a drastic change . . . in its school system, the St. James Parish School Board and its staff strongly believes [sic] that separation of the sexes at the high school and upper elementary levels is the best plan to offer the community at this time.

Banks v. St. James Parish, Civil No. 16173 (E.D. La. 1969) (School Board's Proposed Amendments to Plan) (emphasis added). See also Moore v. Tangipahoa Parish, 304 F. Supp. 244, 249 (E.D. La. 1969) ("The School Board has advanced this plan as an experiment.") 
stereotypes, misunderstandings, and hatreds which are inherent in racial segregation, ${ }^{144}$ and, thus, total integration will be easier when it comes some time in the future. Possibly, after the races are integrated along sex lines, a step in the right direction, many of the attitudes about the sexual prowess of black boys and black girls which exist in the racially segregated context will be erased, then sex separation will become unpopular on its own, and it will die out without judicial intervention. This is a case, the argument runs, "where the State has done as much as it can as fast as it can."145

This justification must be squared, however, with the clearly pronounced policy of the Supreme Court against delay repeated with increased emphasis numerous times since Brown first called for desegregation "with all deliberate speed." 146 For example, in its last terms the Court stated:

[C]ontinued operation of segregated schools under a standard of allowing 'all deliberate speed' for desegregation is no longer constitutionally permissible. Under explicit holdings of this Court, the obligation of every school district is to terminate dual systems at once and to operate hereafter only unitary schools. ${ }^{147}$

Constitutional rights, such as the right to equal educational opportunities, are present rights, and so they were even under the now discarded doctrine of "separate but equal."148 Delays have not been allowed in non-education areas. ${ }^{149}$ The passage of Title VI of the 1964 Civil Rights $\mathrm{Act}^{\mathbf{1 5 0}}$ and other governmental efforts in the area of desegregation may be interpreted as a mandate for a stepped-up pace in enforcing desegre-

144 See text at note 77-83 supra.

145 Buck v. Bell, 274 U.S. 200, 208 (1927). See McLaughlin v. Florida, 379 U.S. 184, 194 (1964).

146349 U.S. at 301 (1955).

147 Alexander v. Holmes County, 396 U.S. 19 (1969). For reaction to this case reflecting some of the justifications discussed in this comment, see N.Y. Times, Oct. 31, 1969, at I. The policy of immediate desegregation enunciated in Alexander can be seen in numerous cases decided since Brown. See Green v. New Kent County, 391 U.S. 430, 438-9 (1968); Rogers v. Paul, 382 U.S. 198, 199 (1965); Bradley v. School Bd., 382 U.S. 103, 105 (1965); Griffin v. County School Bd., 377 U.S. 218, 234 (1964); Cooper v. Aaron, 358 U.S. 1, 15-20 (1958); cf. Watson v. Memphis, 373 U.S. 526, 529-30 (1963).

148 See, e.g., McLaurin v. Oklahoma, 339 U.S. 637 (1950); Sweatt v. Painter, 339 U.S. 629 (1950); Sipuel v. Bd. of Regents, 332 U.S. 631 (1948).

140 See, e.g., Boynton v. Virginia, 364 U.S. 454 (1960) (transportation); Bhd. of Railroad Trainmen v. Howard, 343 U.S. 768 (1952) (employment rights and union representation); Schnell v. Davis, 336 U.S. 983 (1949) (voting); Richmond v. Deans, 281 U.S. 704 (1930) (racial zoning of property).

15042 U.S.C. \$2000(e), et seq. (1964). 
gation. ${ }^{151}$ It seems clear that temporary steps are no longer enough: "delays in desegregating school systems are no longer tolerable."152

\section{The Community Hostility Defense}

Admittedly, a school board in the South will often encounter a significant amount of community hostility as a reaction to any attempts at school desegregation. It has been asserted that community hostility to school desegregation and the results which flow from that hostility, such as flight by white children from the public school system, ${ }^{153}$ are a valid reason to integrate the races along sex lines first and bring about total integration later. ${ }^{154}$ This argument, it should be noted, once again admits that race and racial attitudes are being considered in the formulation of a plan, yet seeks to justify this fact.

Today, no less that fifty years ago, the solution to the problems growing out of race relations in the United States "cannot be promoted by depriving citizens of their constitutional rights and privileges."155

151 See Green v. New Kent County, 391 U.S. 430, 433-4 (1968). "We read Title VI as a congressional mandate for change-change in pace and method of enforcing desegregation." United States v. Jefferson County, 372 F.2d 836, 852 (5th Cir. 1966), adopted en banc, 380 F.2d 385 (5th Cir.), cert. denied, 389 U.S. 840 (1967).

152 Bradley v. School Bd., 382 U.S. 103, 105 (1965). See Alexander v. Holmes County, 396 U.S. 19 (1969). On the use of educational devices which delay school desegregation, see Hobson v. Hansen, 269 F. Supp. 401 (D. D.C. 1967), aff'd sub nom., Smuck v. Hobson, 408 F.2d 175 (D.C. Cir. 1969). For a consideration of the use of sex separation as an educational experiment, see pp. 323-6 infra.

153 Respondent's argument in this Court reveals its purpose. We are frankly told in the Brief that without the transfer option it is apprehended that white students will flee the school system altogether.

Monroe v. Bd. of Comm'rs, 391 U.S. 450, 459 (1968).

This pairing method [sex separation] in the City of Bastrop will not cause whites to move about seeking to flee predominantly Negro areas, thereby resegregating the schools.

United States v. Morehouse Parish, Civil No. 14429 (W.D. La. 1969) (School Board's Proposed Plan). See N.Y. Times, Oct. 31, 1969, at 1.

154 [I]n making a transition of this type, we have to consider the opinion of our people, public opinion .... This problem will be difficult, but if we could have the support of our public this would minimize the problems that we will be confronted with.

Record at 12, Banks v. St. James Parish, Civil No. 16173 (E.D. La. 1969) (testimony of the Superintendent of Schools).

$[\mathrm{Y}]$ ou might say the acceptance of the public in the local community is a prime factor in operating a school system, because unless you have public support, the school system would not be able to operate very long.

Id. at 79 .

It might make racial integration somewhat more palatable to those of the blindly bigoted whose resistance is partly created by insecurity and fears regarding sex.

Levine, Coeducation-A Contributing Factor in Miseducation of the Disadvantaged, 46 Phi Delta Kappan 126, 128 (1964).

See also Moore v. Tangipahoa Parish, 304 F. Supp. 244, 249 (E.D. La. 1969); Smith v. St. Tammany Parish, 302 F. Supp. 106, 108 (E.D. La. 1969).

155 Buchanan v. Warley, 245 U.S. 60, 80-81 (1917). See Cooper v. Aaron, 358 U.S. 1, 6 (1958); cf. Watson v. Memphis, 373 U.S. 526, 539 (1963). 
Hostility to constitutional precepts was expressly proscribed by Brown as a valid justification for delay in school desegregation. " $[1]$ t should go without saying that the vitality of these constitutional principles cannot be allowed to yield simply because of disagreement with them."158 As a court determines the legitimacy of this suggested justification for the sex separation plans, the words of Mr. Justice Frankfurter, uttered in the face of massive resistance to school desegregation are relevant:

Local customs, however hardened by time, are not decreed in heaven. Habits and feelings they engender may be counteracted and moderated. Experience attests that such local habits and feelings will yield, gradually though this be, to law and education. And educational influences are exerted not only by explicit teaching. They vigorously flow from the fruitful exercise of the responsibility of those charged with political official power and from the almost unconsciously transforming actualities of living under law. ${ }^{\mathbf{1 5 7}}$

\section{The Defense from the Educators}

Probably the most persuasive justification of sex separation schemes comes from the educators. The fact that their defense of sex separation originates in a context far removed from the realities of the segregated South, ${ }^{158}$ and has been articulated by the Catholic church in one form and by the defenders of private all-boys and all-girls schools in another form, gives the argument an aura of respectability. ${ }^{159}$

156 Brown v. Bd. of Educ., 349 U.S. 294, 300 (1955); accord, Monroe v. Bd. of Comm'rs, 391 U.S. 450, 459 (1968); Griffin v. County School Bd., 377 U.S. 218, 231 (1964); Cooper v Aaron, 358 U.S. 1, 9 (1958).

157 Cooper v. Aaron, 358 U.S. I, 25 (1958) (Frankfurter, J. concurring).

158 Most of the research cited herein was done in all-white, middle class contexts and is very limited in scope. The single exception to the all-white, middle class context seems to be Levine, supra note 154 . His conclusion is of particular interest.

To summarize, a coeducational classroom in low-income communities simultaneously encourages boys to act out scholastically disfunctional stereotypes and increases the likelihood that they will experience competitive lack of success which confuses their sexual identification and threatens their self-image.

Id. at 128.

159 This defense has been accepted in at least one case.

There is no objection to the assignment of school children to schools on the basis of sex; no federal court has at any time claimed such an assignment to be unconstitutional; and the government in this case does not enter objection to that concept. As a matter of fact, "coeducation," the education of girls in the same schools that boys also attend, has been regarded as a "modern phenomenon." Encyclopedia Britannica, Vol. VI, page 14. Historically the education of youths was on the basis of separation of the sexes, and it was not until approximately 1900 that most public high schools were coeducational. According to good authority, "opponents of coeducation at the elementary level have argued that girl's nature is so different from that of boy's that a different kind of education is required, especially from the age of 12." Encyclopedia Britanica, page 15. This observation is pertinent only to show that the philosophy of teaching young people on a basis of separation by sex is respectable and has behind it a certain 
Pope Pius XI in his historic encyclical "The Christian Education of Youth" defended sex separation in education and refers to coeducation as "false" and "harmful" and based on "a deplorable confusion of ideas that mistake a leveling promiscuity and equality for the legitimate association of the sexes." He concludes: "there is not in nature itself, which fashions the two [sexes] quite different in organism, in temperament, in abilities, anything to suggest that there can or ought to be promiscuity, and much less equality, in the training of the two sexes."160 The Catholic defense of separate education, although based peripherally on other considerations, ${ }^{\mathbf{1 6 1}}$ is primarily concerned with the prevention of immorality and promiscuous behavior through the separation of the sexes during the educative process. Although the state may have a legitimate interest in the prevention of promiscuity which it manifests in the form of various sex laws, the basic premise-that coeducation may be equated with promiscuity-is surely open to question. In any case, the countervailing advantages of coeducation may outweigh the asserted danger of illicit behavior. ${ }^{162}$

There has been surprisingly little empirical research done on the psychological and educational merits and demerits of separate education, ${ }^{163}$ and most of it reveals inconclusive findings. ${ }^{164}$ It seems relevant, however, to consider the arguments advanced on both sides. Any court evaluating a sex separation scheme, if it were to be true to the precedent set by the Supreme Court's reliance on the opinion of social scientists in Brown, must look to the educators' view.

In the context of private, secular schools it has been maintained that the differential development, physically and mentally, of boys and girls in the pre-adolescent and adolescent stages requires separate teaching at a different pace in order to realize the fullest intellectual develop-

wisdom of the ages. In any case, the concept embraces a philosophy that has not been held contrary to the United States Constitution and must, therefore, be approved.

United States v. Carroll County, Civil No. GC 6541-K (N.D. Miss. 1969) (Keady, C.J.). The Fifth Circuit apparently would recognize the educational defense.

The court is reluctant to permit the use of such a plan except upon a finding based on proof that the plan was devised and is to be promulgated for educational purposes only.

United States v. Amite County, Nos. 28030 \& 28042 (5th Cir. Dec. 11, 1969) (unreported order of 3-judge panel).

160 Pope Pius XI, The Christian Education of Youth, in Five Great EncychraAls 56-57 (C. Tracy ed. 1939).

161 See generally MCCLuSkEY, supra note 79, at 96-99.

162 See text at notes $165-7$ infra.

163 Levine, supra note 154, at 127; Kolesnik, supra note 79, at 73.

164 Fisher \& Waetjen, An Investigation of the Relationship Between the Separation by Sex of Eighth Grade Boys and Girls and English Achievement and Self-Concept, $59 \mathrm{~J}$. OF ED. REs. 409, 412 (1966); Kolesnik, supra note 79, at 75; Levine, supra note 154, at 127. 
ment of each group. ${ }^{165}$ In separate education fewer discipline problems are said to arise because the tendency of boys to "show-off" for girls does not exist. ${ }^{166}$ Some research has also revealed less pressure and competition when the sexes are separated resulting in more cooperation, motivation, and participation by the separated groups. ${ }^{187}$

Other studies, however, employing similar research techniques, have found no increased intellectual development under sex-separated education when the differential physical and mental development of the two sexes are taken into account. ${ }^{168}$ Behavior may also be better in the coeducational environment as boys try to achieve status in the eyes of girls through school-oriented behavior rather than subversion of the educational atmosphere. ${ }^{169}$

In view of the inconclusive nature of most of the research in this area, a court, before accepting the educational values of separate education as a justification for sex separation in school desegregation plans, would have to see more than the present empirical research reveals.

Probably the most compelling defense of the use of sex separation in school desegregation plans is one which has not yet been advanced in the proceedings which have passed on the validity of the device. It combines, in an educator's argument, all of the defenses discussed above and runs as follows: There is a large disparity between the educational levels of black and white children in the South. ${ }^{170}$ Despite all efforts which have been made to close this gap, the proper method has not been found. ${ }^{171}$ Because separate education has not yet been disproved as an advantageous method for enhancing the educational progress of disadvantaged students, the argument runs, give the sex separation scheme a trial as an educational tool, a way to close the educational gap between the races, before passing on it as a tool of desegregation. It does, after all, integrate the races and afford an opportunity to avoid the hostility which would be encountered by integration of the sexes. Even "freedom-

165 See McCluskey, supra note 79, at 97-98; Dale, supra note 76, at 206; Kolesnik, supra note 19, at 75; Levine, supra note 154, at 127.

168 See Dale, supra note 76, at 201-2; Herman \& Criscuolo, Sex Grouping, 77 THE INSTRUCTOR 97, 99 (1968); Kolesnik, supra note 79, at 75, 81; Levine, supra note 154, at 128; Lyles, Grouping by Sex, 46 Nat'z Elem. Prin. 38, 39 (1966).

167 See Herman \& Criscuolo, supra note 166, at 97; Kolesnik, supra note 79, at 77-78, 81; Levine, supra note 154, at 127; Lyles, supra note 166, at 40 .

108 See Fisher \& Waetjen, supra note 164, at 412; Herman \& Criscuolo, supra note 166, at 98; Lyles, supra note 166 , at 39 .

169 See Dale, supra note 76, at 201-2; Levine, supra note 154, at 127.

170 See J. Colfman, Equality of Educational Opportunity (1966); W. Mendeison, Discrimination 50 (1962).

171 See Coleman, supra note 170. A discussion of some of the attempts to close the scholastic gap between the races is found in MENDELSON, supra note 170, at 50-59. See generally Equal Educational OpPoRTunity (Harvard Educational Review 1969). 
of-choice" and "free transfer" were given at least three years before being struck down for the first time, ${ }^{172}$ and they were not educational tools but rather devices for desegregation. The goal of desegregation is, after all, equal educational opportunity, and the courts have traditionally deferred to the educators when matters of how education may best be transmitted have arisen. ${ }^{173}$

In the last analysis, this defense of sex separation appeals to the "practical flexibility [of the courts] in shaping remedies"174 which was specifically recognized in Brown as a necessary attribute of plan evaluation. Because of its cumulative character, this argument, more than any of the others, will test the courts' facility for 'adjusting and reconciling public and private needs." 175 Whether it will overcome the objections raised earlier in this comment to each of its component parts and satisfy the burden of persuasion associated with school desegregation plans is a question that will soon be answered by the courts. The ultimate relevance of this defense, as well as the relevance of any of the other justifications which may be offered for sex separation plans, will depend on the test the court chooses to use in evaluating the success of the plans in achieving equal educational opportunities. What might be "reasonably related" to achieving equal educational opportunities might not be "necessary" to achieving that goal.

\section{Conclusion}

The use of sex separation in school desegregation plans raises three important issues of constitutional dimension. These include the extent to which the scheme perpetuates the racial discrimination forbidden by Brown, the validity of the sex classification, and the limits of the fundamental freedom to associate. Given the presence of these issues in the use of the sex separation schemes and the burden of proof normally placed on the school boards in plan evaluation, it would seem that better justifications than those which have thus far been advanced would be needed if the boards are to persuade the courts of the validity of this particular scheme. In the final analysis, the courts, in evaluating the sex-separation plans, will be primarily concerned with the existence of racial discrimination in the use of the device. If the courts do not

172 See Monroe v. Bd. of Comm'rs, 391 U.S. 450, 457 (1968); Green v. New Kent County, 391 U.S. 430,441 (1968).

173 See Brown v. Bd. of Educ., 349 U.S. 294, 299 (1955); Stell v. Savannah-Chatham County, 333 F.2d 55, 6I-62 (5th Cir.), cert. denied, 379 U.S. 933 (1964); Moore v. Tangipahoa Parish, 304 F. Supp. 244, 249 (E.D. La. 1969). But see Hobson v. Hansen, 269 F. Supp. 401 (D.D.C. 1967), aff'd sub nom., Smuck v. Hobson, 408 F.2d 175 (D.C. Cir. 1969).

174 Brown v. Bd. of Educ., 349 U.S. 294, 300 (1955).

$175 \mathrm{Id}$. 
overturn the use of sex separation in school desegregation plans, they will be sanctioning racial discrimination by validating plans which perpetuate a vestige of the racial caste system and foster the very harms declared unconstitutional over fifteen years ago in the School Desegregation Cases. 